\title{
PELAGIUS AND THE PAULINE TEXT IN THE BOOK OF ARMAGH.
}

THE question what text was used by Pelagius as the basis of his commentary on the Epistles of St Paul has been answered by Simon, on the basis of the printed editions of Pseudo-Jerome, by Zahn, on the basis of Zimmer's collation of the anonymous MS 73 at St Gall, and by myself, on the basis of the non-interpolated Reichenau MS Irg at Karlsruhe, as the Vulgate. The evidence of the last authority is given, so far as the Epistle to the Romans is concerned, in Wordsworth and White's edition of the epistle (Oxonii, I913). The Reichenau text is not at all identical with the text approved by Wordsworth and White, and this fact, joined to certain other phenomena in the text of the other epistles, has created a doubt whether after all it was the Vulgate text that was used by Pelagius, in spite of the occurrence of porro at I Cor. vii 35, a word entirely absent from the Old-Latin.

MS 157 of Balliol College, Oxford, written by an Italian scribe about the middle of the fifteenth century, doubtless to the order of Bp William Gray, who gave it to the College, has the name of Jerome in the title, but is almost, if not entirely, devoid of interpolation of any sort. But what is perhaps more interesting is this, that it provides a text of the Epistles which is Old-Latin right through. It is in constant agreement with certain European non-Vulgate manuscripts and citations, and shews a specially close relationship with the text in the Book of Armagh, being not infrequently in solitary agreement with it in striking readings. The detailed proof of this will be presented elsewhere, but meantime one is moved to ask whether it is not more natural to suppose that Pelagius used an Old-Latin text, which was in certain copies like Reichenau 1 I 9 harmonized almost perfectly with the Vulgate, than to regard Balliol $I_{57}$ as a descendant of a copy in which an original Vulgate text was perfectly altered to an earlier type. The Book of Armagh contains the Pelagian prologues under their author's name, and its Pauline text is, I believe, copied out of a manuscript of the Pelagian commentary, where the Biblical text had been somewhat harmonized with the Vulgate. The Balliol MS represents an altogether purer strain. It may be mentioned that both lack porro at I Cor. vii 35 .

\section{A. SOUter.}

